\title{
Development of new design-technological scheme of harvesting haulm of sugar beet with the use of a tillage-row-crop tractor
}

\author{
Ye. Ignatyev \\ Tavriya State Agrotechnological University
}

The purpose. To develop and test under production conditions the new combined assembly unit for harvesting haulm of sugar beet with the use of integral tillage-row-crop tractor. Methods. Method of use of machines in plant growing, experimental researches and field tests of farm machines, and also evaluation procedure of quality factors of their operation. Results. New design-technological scheme of harvesting haulm of sugar beet is developed and justified with application of integral tillage-row-crop wheeled tractor of tractive class 3. At use of wheeled tractor of such type the necessary condition is the availability of fast-head and rear hinged gears and shaft of output couplings, and also adjustment of its wheels for the necessary width of row widths of sowings of sugar beet. The production process of harvesting haulm of sugar beet is carried out in 2 stages: top-gathering machine frontally positioned on a tractor realizes the basic solid shearing of all array of haulm and loads it into transport equipment. Conclusions. The designed and tested combined assembly unit for harvesting haulm of sugar beet stably executes production process and has quite high quality factors of harvesting. However at operation of that top-gathering machine the percentage of crushing leaves of haulm $(60-65 \%)$ is too high occurs at its solid shearing and loading.

Key words: sugar beet, harvesting, haulm, cutting off, combined assembly unit, tillage-row-crop tractor, mechanicallyflow sheet.

Formulation of the problem. One of the key issues in the technological process of harvesting sugar beets is the removal and harvesting of hips from the root crop heads at the root. Since the lump of sugar beet is a sufficiently valuable source of animal feed, as well as good raw material for biogas production, the necessary, first and foremost, condition for its harvesting is the complete cutting of the whole green mass from the root crop heads, assembly and transportation to the place of use without any loss. Important conditions for the high-quality harvesting of sugar beet tops are also the absence of green plant residues on the heads of the root crops, the damage of the heads of the root crops themselves and their knocking out of the soil. The contamination of the collected wedge with soil impurities is also an unacceptable phenomenon.

Recently, the world's most widespread technology for harvesting sugar beet hinges is the technology, which initially provides a continuous, uncompromising cut of the main (green) mass of the hips along the entire width of the hook, the collection of the vehicle, and transportation to feeding areas, silos or biogas installation. In the future, separately, a section of the top of the head of the root is provided, which contains the remains of the hook using the individual copy and the simplest passive knife. Of course, with such cutting, the upper part of the cut off head of the root was lost. Accordingly, for this technology, the development of working bodies of hoeing machines was carried out and their necessary layout was implemented to meet the requirements of the technological process. Beet-harvesting machines of the modern technical level are built precisely according to such a technological scheme, that is, hook-picking modules of corncrapers and combines, which are now produced in the world, carry out exactly such a two-stage cut of sugar beet huckster.

However, studies have shown that with such a trimming and corresponding losses of the upper parts of the heads of root crops sugar beet sometimes lost about $14 . . .17 \%$ of the sugar mass (especially in the case of increased trimming of heads). Therefore, the problem of cleansing sugar beet root crops from 
residues of the gill (green as well as dry) without loss of sugar mass is an actual, economically justified scientific and technical problem..

Analysis of recent research and publications. Many works published by L.V. are devoted to the study of the work of hoisting machines of the modern technical level. Burned up, VM Bulgakov, MM Zueva, MM Boris V.Ya. Martynenko, SA Topovsky, AM Boris and others. They have substantiated and analyzed basically separate lycko harvesting and finishing machines in order to substantiate the rational cut height or reduce root crop damage $[1,3,4,5,6]$. However, little research was carried out on the combination of cutting operations and post harvesting of horseradish of root crops within a single combined unit on the basis of a class 3 propulsion tractor. Therefore, there is a need for additional research that would affect the development of a rational design and technological scheme of such an aggregate and determine its operational and technical parameters.

The aim of the study. Develop and test in production conditions a new combined aggregate for collecting sugar beet tops using an integral spin-wheel drive tractor.

Research methods. In the course of the research, the methods of machine use in crop production, methods of experimental research and field tests of agricultural machines, as well as methods for evaluating the quality of their work are used.

Research results. Based on previous research and design work $[2,7,8,9]$, we have developed a new constructive and technological scheme for collecting sugar beet hinges using an integral ornamentally-driven wheeled tractor, a traction class 3 . In this case, the specified type of tractor having front and rear coupling devices and respectively the front and rear power take-off shafts, as well as adjustment of its running wheels with narrow tires to the desired width of rows of sugar beet crops, mounted front mounted hitch a jigsaw machine that carries a solid, dull, unprotected cut of the main body of the hinge, its assembly and loading into the vehicle. Behind the tractor, a cleanser of the root crops is attached to the tractor, which carries out the final cleansing of the root crops from the remains of the hoof of each row of pre-cut crop roots with the help of flexible cleaning blades mounted on the vertical drive shafts. During the execution of all technological operations, the mechanical and technological properties of root crops and hinges were taken into account in order to minimize damage to sugar beet heads and shredding leaves [10].

In fig. 1 introduces a new design and technological scheme of the front-mounted hinged machine and a rear-mounted head cleaner from the root crop from the remains of the hinge to an integrated harnesspropulsion tractor.

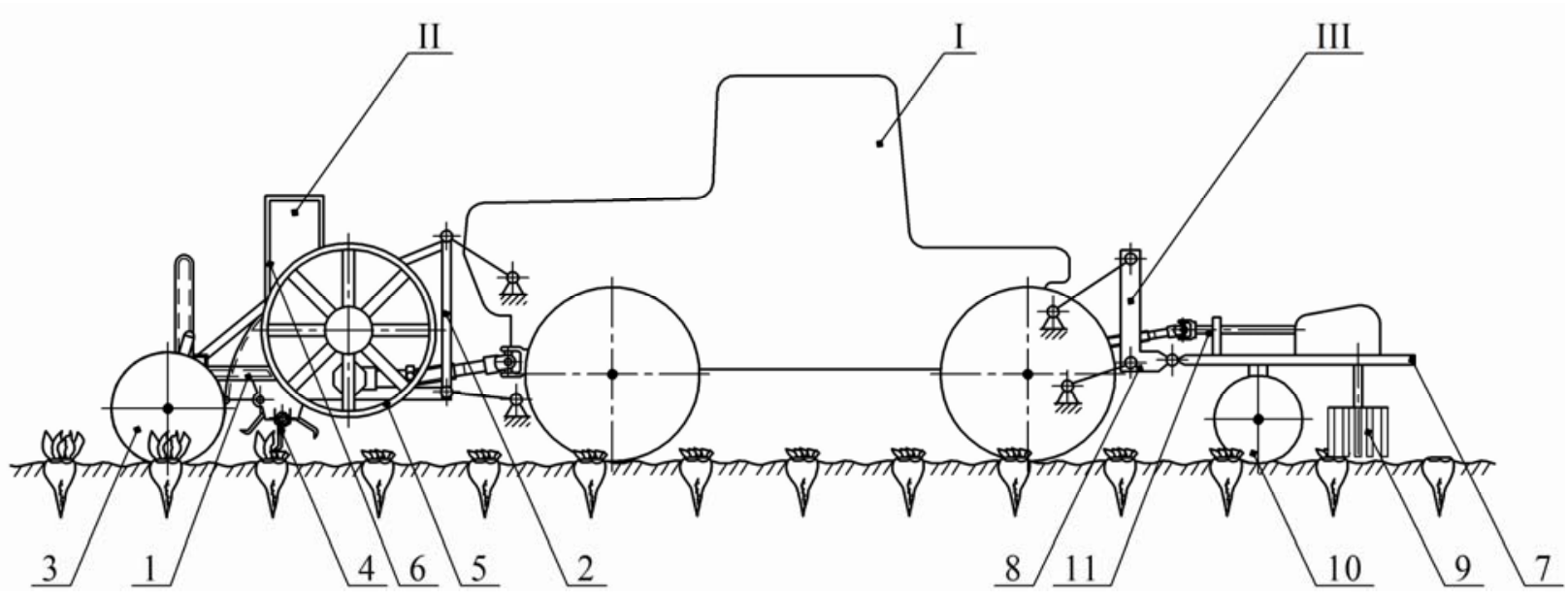

Fig. 1. Unit for collecting sugar beet tops:

I - a tractor;

II - front-mounted hinged machine:

1 - frame; 2 - coupling device; 3 - copier wheel;

4 - rotary hiccirculator; 5 - transporting submission working body; 6 - boot device;

III - cleaner of heads of root crops from remnants of tops:

7 - frame; 8 - coupling device; 9 - cleaning shaft; 10 - copier wheel; 11 - drive. 
In fig. 2 gives the appearance of a front-mounted hinged machine in 3-row execution.The technological process of collecting sugar beet tops is carried out in this way. The front-mounted on the catch 2, the hook-making machine II carries out a continuous, uncompressed cut of the hinge mass at the overheated installation of its 4-rotor type shearing machine, which is provided by the copper wheels 3 with the adjustment mechanisms of the height. The technological process of direct cutting the mass of the hinge by the hinged hook assembly I occurs as follows: the hinge is cut off by a rotary gyro cutting device 4 located on a frame 1, which has flat-knife S-shaped shaped joints mounted on the drive drum. In this case, the rotary shearing cutter 4 has a counter-direction of the rotational motion of the cutting drum, and therefore its knives are mounted on the drum in such a way that their cutting parts overlap the entire plane of the capture area of the hoisting machine, lifting the cut weight of the tops upwards. Next, it enters the transport and supply working body 5 , which has a transverse screw conveyor, the length of which is equal to the width of the hook of the hoisting machine, at the end of which a shovel shaft 6 is installed. Then, with the aid of the shipment, that is, the shaft 6 , the cut weight of the hoop rises upwards and loaded into the body of the vehicle moving alongside the collected part of the field.

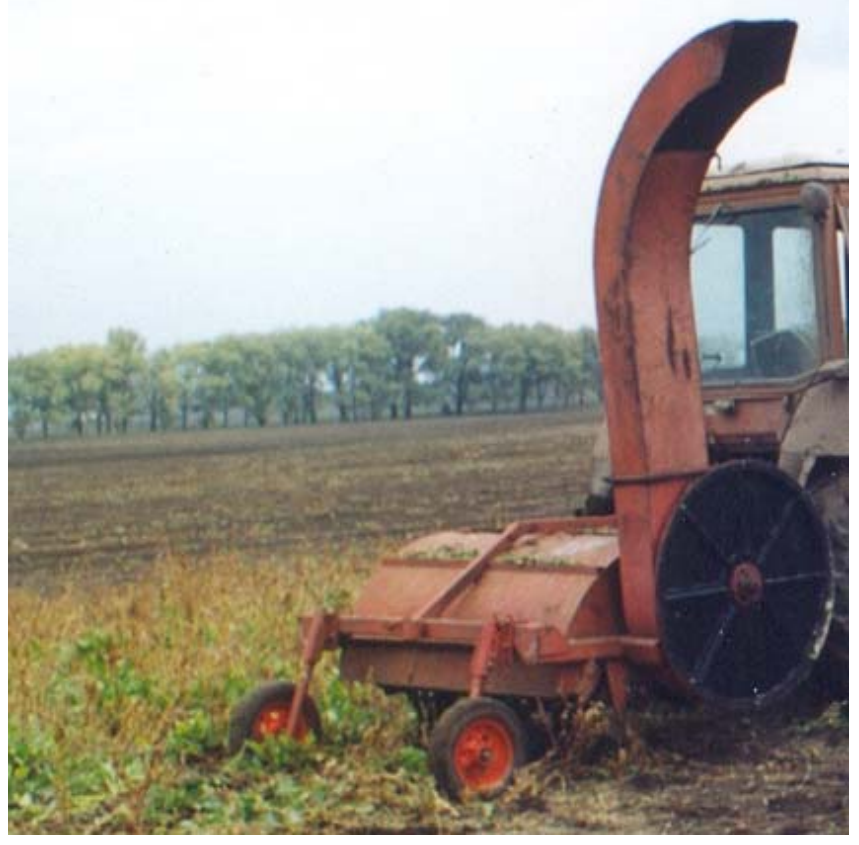

Fig. 2. A three-row implements frontal hinged on a wheeled tractor

The final cleansing of sugar beet root crops from the remains of the hinge is carried out by a rearmounted clutch purifier III, which is mounted behind the tractor by means of the coupling device 8 . The head cleaners of the root crops from the remains of the hinge III have mounted on the frame 7 cleansing shafts 9 (individual cleaning lines for each row) ) with vertical axis rotation and containing consolemounted ends of the elastic cleaning blades. Elastic shovel shafts 9 moving progressively along a row of array of sugar beet root crops on the height of the set with copying wheels 10 and at the same time rotating with a certain rotational speed effectively separates the remnants of the hoof from root roots of the root without damaging them and not knocking out of the soil. The actuator 11 provides the rotation of all shafts (in 3-row or 6-row execution) of root crop head cleaners III.

In fig. 3 gives a view of a single cleaning shaft installed on the cleanser of root crops during research. 


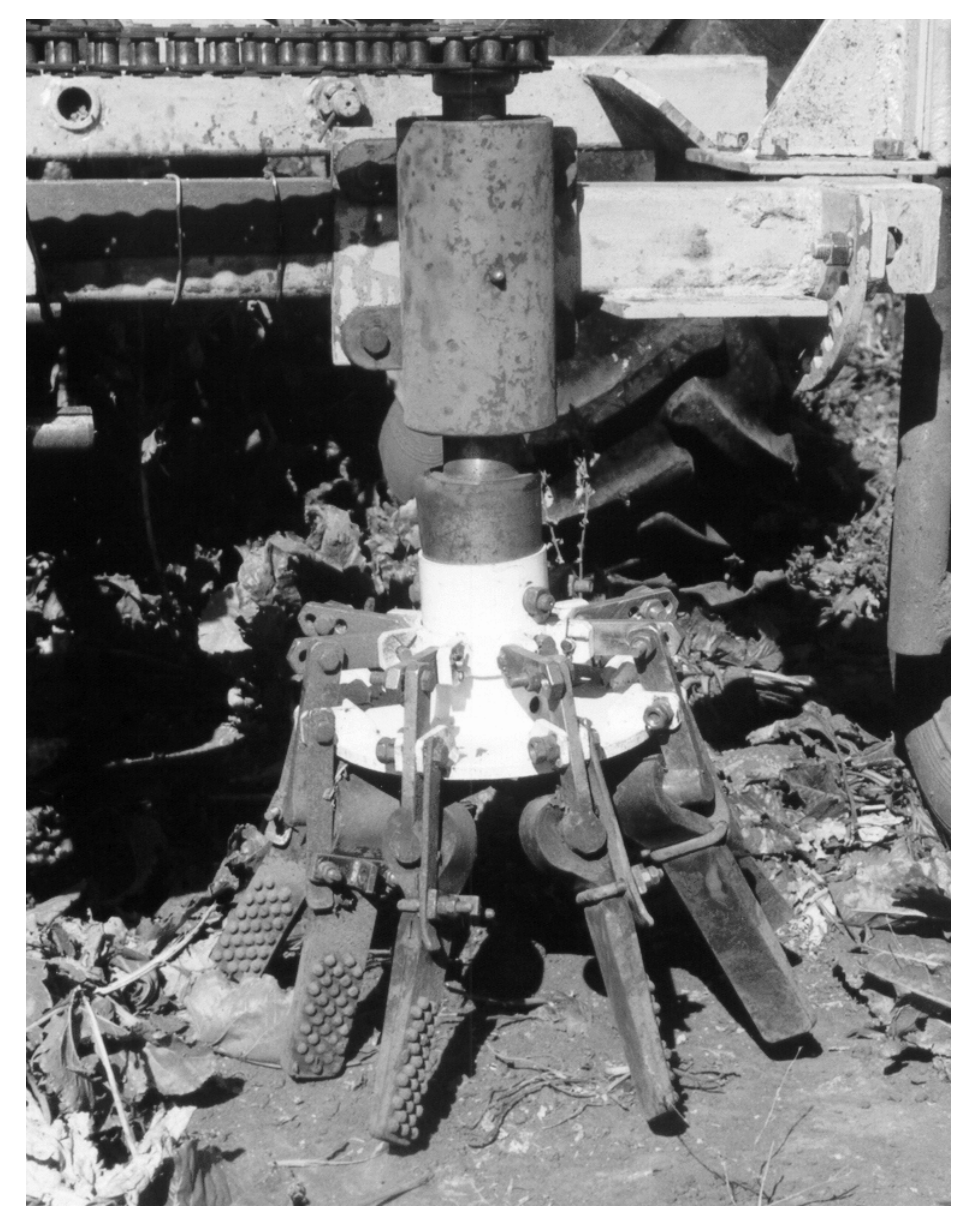

Fig. 3. Cleansing shaft of cleanser of heads of root crops

As a result of experimental research and field trials of a jig-maker, made in the 3-row version, for a wheeled tractor of the traction class 1.4 , it was established that the harvesting capacity of the jig is $1.5 \ldots$ $1.7 \mathrm{ha} / \mathrm{h}$. The capacity for the continuous process of cutting the sugar beet hinge with a self-winding machine is $8.5 \ldots 14.5 \mathrm{~kW}$, and the tractive power does not exceed $5 \mathrm{~kW}$. The best quality performance of the hoeing machine, this design (the completeness of the continuous cutting of the hook - up to $80.5 \ldots$ $90.0 \%$ ) was obtained at the rotational speed of the rotary cutting machine $800 \ldots 950 \mathrm{~min}-1$, and the height of its installation above the level of the soil surface $-0.04 \ldots 0,06 \mathrm{~m}$. When using a three-row cutting machine, the number of clipped tops is about $95 \ldots 98 \%$. The degree of damage to root crops does not exceed $5 \%$, which is within agrovimage. However, with the continuous cutting of the tops, there is a too high percentage $(60 \ldots 65 \%)$ of crushing its leaves and stems.

The next stage of the study will be the development of a mathematical model of the fluctuations of the harvesting machines and the head cleaners of root crops from the remains of the hinge, taking into account the oscillations of the aggregating energy source.

\section{Conclusions}

Important problems in collecting sugar beet tops can be solved by the development and application of combined machine-tractor units, which are built on a modular principle and provide significant advantages in terms of their use in production conditions.

A new design and technological scheme for collecting sugar beet hinges using an integral ornonpropeller tractor allows for the implementation of a specified process, in which a high-quality cutting of the main mass of the hook occurs, its complete harvesting and subsequent use for feeding animals or for the production of biogas. This is done by the front-mounted hitching machine on the wheeled aggregate 
tractor. The cleansing of the heads of root crops from the remains of the hickey successfully implements the rear-mounted root crop head cleaner on the tractor.

According to the results of experimental and field studies, the performance of the hinge assembly in the 3-row performance of the hoeing machine (with the use of a wheeled tractor of the traction class 1.4) is about $1.7 \mathrm{ha} / \mathrm{h}$, the power of this process does not exceed $15 \mathrm{~kW}$, and the completeness the continuous cutting of the grip can reach $90 \%$.

\section{References}

1. Pogorelyiy L. V. Sveklouborochnyie mashinyi: istoriya, konstruktsiya, teoriya, prognoz/L.V. Pogorelyiy, N. V. Tatyanko. - K.: Feniks, 2004. - 232 s.

2. Boris A. N. Modelirovanie tehnologicheskogo protsessa otdeleniya botvyi kombinirovannyim sposobom/A. N. Boris//Vestnik agrarnoy nauki. -2011. - Vyip. 7. - S. 66-68.

3. Bulgakov V. M. Sveklouborochnyie mashinyi/V. M. Bulgakov. - K.: Agrarnaya nauka, 2011. - $352 \mathrm{~s}$.

4. Martyinenko V. Ya. Botvouborochnyie mashinyi/V. Ya. Martyinenko. - Ternopol: Poligrafist, 1997. $110 \mathrm{~s}$

5. Toporovskiy S. A. Obosnovanie tehnologicheskogo protsessa i osnovnyih parametrov rabochego organa dlya uborki botvyi saharnoy sveklyi bez kopirovaniya golovok korneplodov: avtoref. dis... kand. tehn. nauk: spets. 05.20.01/S. A. Toporovskiy. - KiYiv. - 1988. $-19 \mathrm{~s}$.

6. Boris N. M. Obosnovanie tehnologicheskogo protsessa i parametrov rabochego organa dlya otdeleniya botvyi saharnoy sveklyi: avtoref. dis. na zdobuttya nauk. stupenya kand. tehn. nauk: spets. 05.05.11/N. M. Boris. - Vinnitsya: VDAU, 2009. - $20 \mathrm{~s}$.

7. Kromer K.-H., Strätz J. und Tschepe M. Technischer Stand der Zuckerrübenernte - Rodertest Seligenstadt 2000//Landtechnik. - 2001. - №56. H. 2. - P. 78-79.

8. Lammers P.-S. Harvest quality of six-row sugar beet tanker harvesters/P.-S. Lammers, M. Rose//Landtechnik. - 2005. - №60., H. 5. - P. 252-253.

9. Helemendik M. M. Napryami i metodi rozrobki novih robochih organiv silskogospodarskih mashin/ M. M. Helemendik. - K.: Agrarna nauka, 2001. - $280 \mathrm{~s}$.

10. Mehaniko-tehnologicheskie svoystva selskohozyaystvennyih materialov: praktikum/[Tsarenko O. M., Yatsun S.S. i dr.]; Pod red. S. S. Yatsuna. - K.: Agrarnoe obrazovanie, 2000. - 93 s. 